\title{
A Data Driven Conceptual Analys is of Globalization - Cultural Affects and Hofstedian Organizational Frames: The Slovak Republic Example
}

\author{
Gary J. DeLorenzo \\ California University of \\ Pennsylvania, California, PA, USA \\ delorenzo@cup.edu
}
Vladimir Burčik \& Alžbeta Belanová
Comenius University, Bratislava, Slovakia

burcik@ilearn.sk; belanova.bet@gmail.com

\author{
Frederick G. Kohun \\ Robert Morris University, \\ Pittsburgh, PA, USA \\ kohun@rmu.edu
}

Robert Joseph Skovira

Robert Morris University, Pittsburgh PA, USA

skovira@rmu.edu

\begin{abstract}
It has been argued that culture effects how individuals implement, understand, live, and do business within a defined political, organizational, and ethnic environment. This essay presents a context for analyzing possible cultural shifts based on Hofstede and Hofstede's conception that a society's culture constituted in and presented in individuals' views and routines determines an identifiable cultural profile. In particular, Hofstede's indices on Power Distance, Uncertainty Avoidance, Masculinity and Individuality are applied to two populations—one a United States university population and the other from a Slovak Republic university. The overall purpose is to determine if Hofstede's orginal research findings are the same today in an era of the internet, globalization, and economic change.
\end{abstract}

Keywords: globalization and change, global education, organizational cultural, Hofstede, cultural patterns, business education

\section{Introduction}

It has been argued that culture effects how individuals implement, understand, and teach the curriculum of business courses within a society's educational institutions (Burčik et al., 2007; DeLorenzo et al., 2006; Hofstede \& Hofstede, 2005). As an example, the curricula and their subject

Material published as part of this publication, either on-line or in print, is copyrighted by the Informing Science Institute. Permission to make digital or paper copy of part or all of these works for personal or classroom use is granted without fee provided that the copies are not made or distributed for profit or commercial advantage AND that copies 1) bear this notice in full and 2) give the full citation on the first page. It is permissible to abstract these works so long as cred it is given. To copy in all other cases or to republish or to post on a server or to redistribute to lists requires specific permission and payment of a fee. Contact Publisher@InformingScience.org to request redistribution permission. matter reflect the societies in which the curricula are developed and in which they are taught.

The essay presents a contextual case for analyzing this curricular phenomena based on Hofstede and Hofstede's (Hofstede \& Hofstede, 2005) conception that a society's culture constituted in and presented in individuals' views and routines is determinate of a changing 
and increasingly global world. The essay includes a comparative analysis of two university populations-one each from the Slovak Republic and the United States. Finally, Hofstede's Value Survey Module 1994 Questionaire and resulting indices on Power Distance, Uncertainty Avoidance, Masculinity, and Individualism dervived from one university within the Slovak Republic and the United States are compared to Hofstede's original study, analyzed and discussed.

\section{The Global and the Local}

The global is always at odds with the local. Friedman (2000) used the metaphors of "Lexus" and "Olive Tree" to evoke the conflictive and tension-filled relationships between the push of modernity and the pull of tradition. Friedman's concept of globalization emphasizes that there is a unifying and homogenizing system of markets, societies, and information networks worldwide, which are leveling and standardizing forces: the push of modernity. Standardizing forces are homogenizing.

For instance, an aspect of the global is the movement of The Association to Advance Collegiate Schools of Business (AACSB) International, an accrediting body for business and finance education and curriculum, to spread across local situations and to impose educational standards of quality on societies' institutionalized business curricula (Burčik et al., 2008). The result: regional cultural identity meets "global" standardization.

\section{Research and Findings}

\section{The Cultural Matrix}

Culture is the concept we use to explain seemingly patterned behaviors from the perspective of a social group (Burčik et al., 2007, 2008). Culture is the complex matrix of behavior; a shared system of valued sensibilities and practices which influence individuals' habitual ways of saying and doing things. Culture is all the things taken-for-granted and presumed as a basis for communication. Culture refers to the usual ways of doing and saying. Culture is the common sense in situations and their affairs and activities. People spend all the ir time learning how and why to act, learning what emotion goes with what cognitive affair, learning how to use language, how to see things, hear things, and touch things, learning things so well that they become habits of experience. For individuals, enculturated and socialized are developmental and evolutionary affairs. Culture is the shared habits of representation, reference, and inference (Burčik et al., 2007, 2008). Every person has an idiosyncratic take on the habits learned (or each person thinks he or she does.) This is particularly evident in the many habits, patterns, and belief structures associated with ethnic identity. A typical habit learned is the habit of dependency (and independency.) Part of this phenomenon is an ability and competence at influencing the sense of a situation as defined by the web of social relationships. Being independent or dependent are important, but being able to influence how situations are finished is more important. Humans learn about this phenomenon even before they can name it. Hofstede and Hofstede (2005) call this the power distance dimension of a culture. Power distance is an important explanatory concept of behavior. Another learned cultural habit is that of dealing with "up-in-the-air" situations or ambiguous situations. This is Hofstede and Hofstede's (2005) dimension of uncertainty avoidance. A combination of power distance and uncertainty avoidance tacitly focuses the cultural ground for people expounding theories of management and marketing. Following Hofstede and Hofstede, a particular society's power distance index and uncertainty avoidance index explain managerial styles, organizational governance, information flows and use, and the scope of authority and responsibility. It follows that a society's relative position to another society in terms of the indices also describes, analyzes and explains business theories used and taught by business faculties to explain to their students how corporate interests work in the "real world." (Gannon, 2001; Geertz, 1973; Hofs- 
tede, 2001; Hofstede \& Hofstede, 2005; Hooker, 2003; Rowe \& Mason, 1989; Trompenaars, 1994).

\section{Power, Ambiguity, Masculinity, and Individualism}

As a hypothesis of situational behavior, power distance allows an explanation of culturally influenced behavior and theories of behavior. Power distance is how the less powerful members of institutions and organizations within a country expect and accept that power is equally distributed (Dooley, 2003; Hofstede, 2001, p. xix; Hofstede \& Hofstede, 2005, p. 46; Hooker, 2003; Huang et al., 2003; Mead, 1994; Steming \& Hammer, 1992). It is also an explanation of the expectations of the powerful or those in positions of power (and influence); their acceptance is as important as anyone's acceptance. From within a culture, expectations, acceptances, and uses are natural. Power distance in a particular culture is a way of interpreting relationships between and among people generally. There is a continuum from small to large power distance and use in situations.

As a hypothesis of situations and their affairs, uncertainty avoidance is an explanation of culturally influenced attitudes towards types of situations and other people and things whose interactivity create the situations. Uncertainty avoidance is defined as a cultural perspective reflecting the extent to which the members of a culture feel threatened by ambiguous or unknown situations (Cyert \& March, 1962, 1992; Hofstede, 1983; Hofstede \& Hofstede, 2005, p. 167; March, 1994; Umanath \& Campbell, 1997). As Hofstede puts it, uncertainty avoidance "... is the extent to which a culture programs its members to feel either uncomfortable or comfortable in unstructured situations" (Hofstede, 2001, p. xix). Uncertainty avoidance is a way of explaining characteristics of situations and relations hips such as control, conflict and competition, or consensus. The strong to weak uncertainty avoidance continuum describes and elaborates the situational contexts: weak may be conflictive; strong may be consensual. The situations are conflictive pushing for consensus or agreeable pulling for conflict (Connor \& Worley, 1991; Hofstede, 2001; Mead, 1994).

The masculinity (femininity) index as identified by Hofstede can be alternately viewed as an achievement vs. nurture metric. Essentially, it is away to view if a culture has asocial focus or one of recognizing and encouraging ambition and measures of achievement. To some extent, it reflects gender influenced roles for that culture (Hofstede, 1983). Finally, the individualism (collectivism) index portrays the cultures emphasis on the individual or society (Hofstede, 1983).

\section{Related Work}

In a previous study by Burčik et al. (2008) using business course descriptions from two Slovak Universities, a few observations were made. The Slovak business program has numerous business courses very specific to the content with respect to the business subjects described. Secondly, globalization is not a generalized segment of the business education, but an economic reality necessitating curricular immersion. Focus is on cultural differences, language and communication-English as the language of business, and policy related to doing business with the European Union (EU) as well as the USA. It is quite noticeable that this Slovak business curriculum offers many levels of language courses of European Union countries as well as English.

Globalization is inherent to this curriculum. It is not an imposed addition to the curriculum but rather a designed practical solution to the economic and social reality that defines the nature of business in the Slovak Republic. It is possible in the Slovak context to contend with the practical issues of doing business in a European market by being able to offer so courses that presumably serve a well-defined need. Furthermore, the curriculum is not restricted to a select common body of knowledge - but goes beyond to address the localized business needs to strengthen or provide an advantage in the global world as defined from a Slovak perspective. 
In the Burčik study, the differences between the Slovak and the U.S. universities were noticeable on some courses in the areas of management, marketing, and organizational behavior (Burčik et. al., 2008):

- Firstly, the Slovak business program is more "local" with content that addresses Slovakian, European and U.S. social conscienousness. The "International Human Resource Management" course addresses practices in Europe in comparison with other district regions (U.S. and Asia).

- Secondly, the curriculum in Slovakia addresses management concepts for both Europe and the U.S. with courses such as "Business in Europe" and "English for Managers" as examples while the U.S. universities offered little course content on business in Europe.

- Thirdly, the American business curriculum can be viewed as "global" and generic in nature with little content on specific social and cultural comparisons, it is strong in business foundations and principles.

The question that surfaces with respect to the core of Hofstede and Hofstede's (2005) work: Can there truly be a standard of business derived from the US that can, in fact, be localized and be made relevant to globalization in a frame other than the EU, China, Japan, and the US (Burčik et. al., 2008)? The EU consists of many localized business cultures forced to operate at an EU level, a global context beyond the bounds of Europe, as well as at the local level. Each facet of business incorporates power distance, ambiguity, and individualism to name a few of the localized cultural dimensions (DeLorenzo et. al., 2006; Hofstede \& Hofstede, 2005).

\section{Hypothesis and Process for Testing}

Our hypothesis is that Hofstede and Hofstede's (2005) power distance, uncertainty avoidance, masculinity, and individualism measures reveals less of an impact of localized culture in today's globalized educational business curriculum environment than was described by Hofstede's (1983) original research.

The motivation for this study was rooted in our belief that with the Internet age and globalization, education and bus iness curriculum reveals lesser societal and cultural differences than from Hofstede's original research in the 1960's.

In this study, Hofstede's Values Survey Module 1994 (Hofstede, 1994) was administered to two distinct populations to ascertain cultural differences that may provide insight as to potential impact of globalization. This questionnaire consists of 26 questions with 24 objective Lickert type questions and two open ended questions addressing nationality (Hofstede, 1994). During spring of 2008 and winter of 2008, the questionnaire was administered to a convenience sample of university students in Slovakia (population 61) and undergraduate business students in the United States (population 32) for a total population of 93. The response of the 93 questionnaires were tabulated, processed, and computed according to the protocol established and used by Hofstede. The weighting of responses and tabulation of results was achieved through the application of Hofstede's formula in an EXCEL spreadsheet.

To support the Internet age and globalization theory, the populations surveyed in this paper (the Slovak Republic and in the United States) reflected an age grouping of 18-22 years of age. The original Hofstede study surveyed professionals working for IBM - presumably, adults for the most part reflecting an age span greater than 22 . 


\section{The Calculation Process: The Slovak Example}

Each question is related to an overall calculation for power distance, uncertainty avoidance, masculinity and individualism. For example, Table 1 shows the power distance formula and calculation for the 61 Slovakian responses.

Table 1. Power dis tance formula and calculations

\begin{tabular}{|l|l|l|}
\hline Question & $\begin{array}{l}\text { Mean } \\
\text { Score/Responses }\end{array}$ & $\begin{array}{l}\text { Hofstede's Value } \\
\text { Survey Module }\end{array}$ \\
\hline Q3 & $122 / 61=2$ & -70 \\
\hline Q6 & $172 / 61=2.82$ & 98.7 \\
\hline Q14 & $223 / 61=3.66$ & 91.5 \\
\hline Q17 & $196 / 61=3.21$ & -64.2 \\
\hline
\end{tabular}

$$
\begin{aligned}
& { }^{(1)} \mathrm{PDI}=-35 \mathrm{~m}(\mathrm{Q} 3)+35 \mathrm{~m}(\mathrm{Q} 6)+25 \mathrm{~m}(\mathrm{Q} 14)-20 \mathrm{~m}(\mathrm{Q} 17)-20 \\
& \mathrm{PDI}=-35 \times 2+35 \times 2.82+25 \times 3.66-20 \times 3.21-20 \\
& \mathrm{PDI}=36
\end{aligned}
$$

\section{Indi vi dualism:}

Q1

Total 61 cases $=107$

Mean score: $107 / 61=1.75$

Q2

Total 61 cases $=143$

Mean score: $143 / 61=2.34$

Q4

Total 61 cases $=125$

Mean score: $125 / 61=2.05$

Q8

Total 61 cases $=95$

Mean score: $95 / 61=1.56$

$\mathrm{IDV}=-50 \mathrm{~m}(\mathrm{Q} 1)+30 \mathrm{~m}(\mathrm{Q} 2)+20 \mathrm{~m}(\mathrm{Q} 4)-$ $25 \mathrm{~m}(\mathrm{Q} 8)+130$

IDV $=-50 \times 1.75+30 \times 2.34+20 \times 2.05-25 x$

$1.56+130$

$\mathrm{IDV}=114.7$

The index normally has a value between 0 (strongly collectivist) and 100 (strongly individualist), but values below 0 and above 100 are technically possible.
Masculinity:

Q5

Total 61 cases $=120$

Mean score: $120 / 61=1.97$

Q7

Total 61 cases $=139$

Mean score: $139 / 61=2.28$

Q15

Total 61 cases $=189$

Mean score: $189 / 61=3.10$

Q20

Total 61 cases $=177$

Mean score: $177 / 61=2.90$

$\mathrm{MAS}=+60 \mathrm{~m}(\mathrm{Q} 5)-20 \mathrm{~m}(\mathrm{Q} 7)+20 \mathrm{~m}(\mathrm{Q} 15)-$ $70 \mathrm{~m}(\mathrm{Q} 20)+100$

MAS $=+60 \times 1.97-20 \times 2.28+20 \times 3.10-70 x$

$2.90+100$

MAS $=31.6$ 


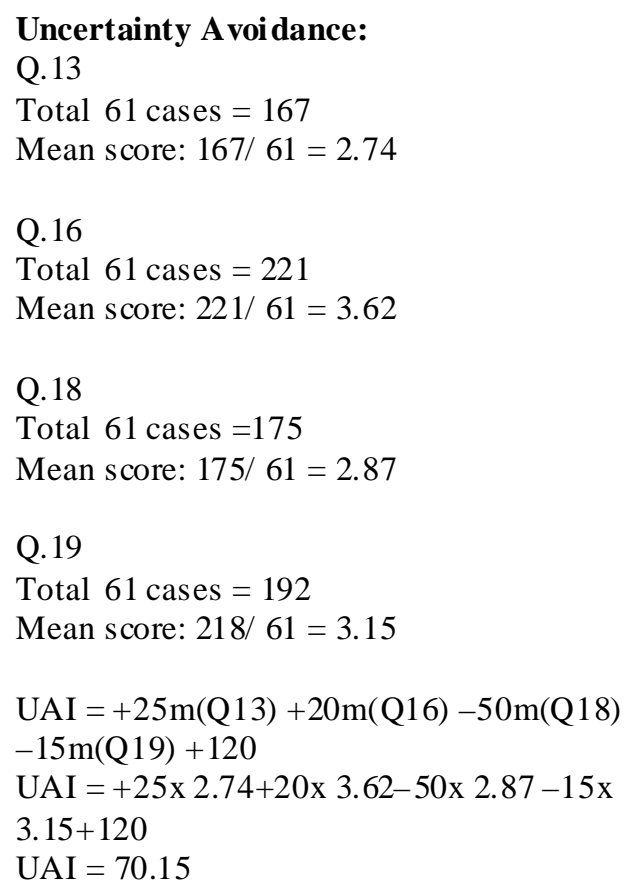

Q9

Total 61 cases $=104$

Mean score: $104 / 61=1.70$

Q10

Total 61 cases $=193$

Mean score: $193 / 61=3.16$

Q11

Total 61 cases $=134$

Mean score: $134 / 61=2.19$

Q12

Total 61 cases $=218$

Mean score: $218 / 61=3.57$

$\mathrm{LTO}=-20 \mathrm{~m}(\mathrm{Q} 10)+20 \mathrm{~m}(\mathrm{Q} 12)+40($ revised version 1999)

$\mathrm{LTO}=-20 \times 3.16+20 \times 3.57+40$

LTO $=48.2$

The formula was originally: $\mathrm{LTO}=$ $+45 \mathrm{~m}(\mathrm{Q} 09)-30 \mathrm{~m}(\mathrm{Q} 10)-35 \mathrm{~m}(\mathrm{Q} 11)+$ $15 \mathrm{~m}(\mathrm{Q} 12)+67$.

\section{The Results}

Table 2 shows the relative calculated indices for Hofstede's Power Distance (PDI), Ambiguity Avoidance (UAI), Masculinity (MAS), and Individualism (IDV) for the population samples from both Slovakia and the United States. What is most striking from the data is that the Slovak indices have changed from the original Hofstede study to become similar to those displayed by the United States. This flattening is true for the PDI, UAI and IDV indices. The MAS index, however, has dropped significantly.

Table 2. Relative Calculated Indices

\begin{tabular}{|l|l|l|l|l|}
\hline & $\begin{array}{l}\text { Current } \\
\text { US }\end{array}$ & $\begin{array}{l}\text { Hofste de } \\
\text { US }\end{array}$ & $\begin{array}{l}\text { Current Slo- } \\
\text { vak }\end{array}$ & $\begin{array}{l}\text { Hofstede } \\
\text { Slovak }\end{array}$ \\
\hline PDI & 32.4 & 40 & 36 & 104 \\
\hline UAI & 48.3 & 46 & 70.15 & 51 \\
\hline MAS & 70 & 62 & 31.6 & 110 \\
\hline IDV & 103.5 & 91 & 114.7 & 52 \\
\hline
\end{tabular}

Figure 1graphically reflects the results of these indices as they are compared side by side. The two most striking changes between the current and original Hofstede study are with the Slovak change from a very high PDI (power distance) to one comparable with the US. Secondly, as mentioned in the "Hypothesis Section", the lower MAS index reveals a greater social-nurturing orientation. The MAS was the only index that revealed the least consistency between the initial Hofstede results for both the United States and for Slovakia. 


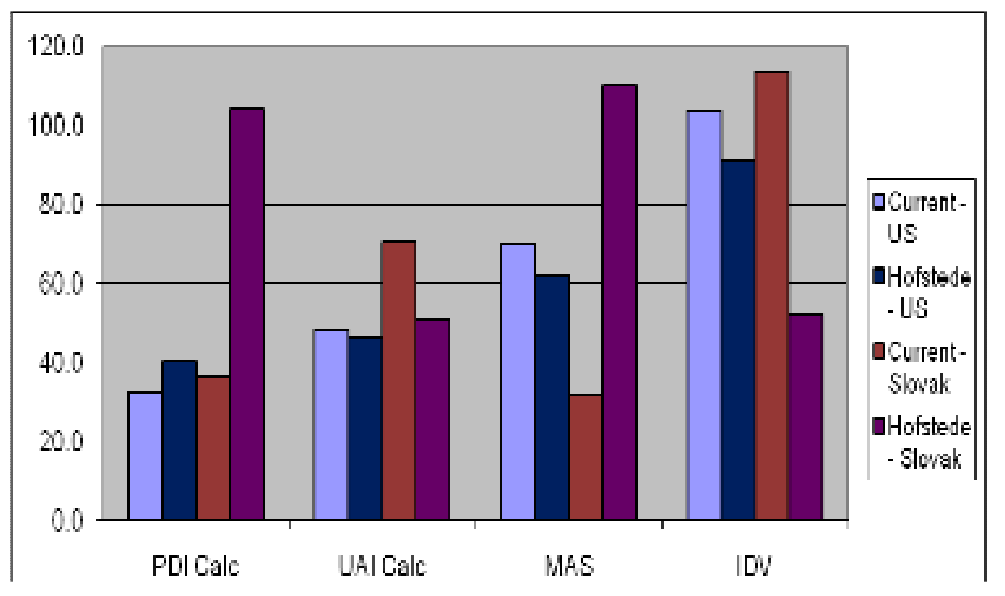

Figure 1. Results of Calculated Indices

\section{Discussion and Conclusion}

This study built on the foundations of two previous studies assessing the impact of globalization on established localized cultural identities. While Hofstede's landmark study in the 1980s provided a key to significant cultural differences between national identities, it can be argued, that the world in which the study was undertaken may no longer exist. The impact of technology (i.e. the computer and the internet) on globalization a long with standardization movements such as international laws, academic accreditations, and most recently the European Union have truly flattened the world. The results from this study have provided additional evidence that, at least in the case of one Eastern European country, that there has been movement to a culturally standard profile. The cultural markers as identified by Hofstede that had characterized many of the countries surveyed can be expected to see change as a result of recent initiatives such as educational standardization (i.e., the Bologna Agreement, AACSB and ABET International accreditation), the internet, and a borderless European Union. From a more theoretical perspective, since 1992 Europe, in particular had moved from what Bolman and Deal (Bolman \& Deal, 1997) would call a structured political frame to one that has encompassed greater risk and uncertainty. Finally, In the case of Slovakia, the social cultural environment of the original research population and our current research group was completely different. Our current students were 2-3 years old in the late 1980s and early 1990s -- a time of great change in Slovakia. As Slovakia evolved out of socialism, the students did not experience life grow ing up in a society driven by a state- planned economy, a market regulated by the state, and a government based on a one party system. They now live in a country that promotes global economic enterprise, an open marketplace for commerce while offering freedoms to pursue those endeavors within the state. So, we can suppose (and the results show it) that they are developing different cultural patterns from the original study, influenced by new socio-economic conditions.

\section{References}

Bolman, L. G., \& Deal, T. E. (1997). Reframing organizations: Artistry, choice, and leadership. 2nd ed. San Francisco, CA: Jossey-Bass.

Burčik, V., Kohun, F. G., \& Skovira, R. J. (2007). Analyzing the affect of culture on curricular content: A research conception. Issues in Informing Science and Information Technology, 4, 381-393. Retrieved fro $\mathrm{m}$ http://proceedings.informings cience.org/InSITE2007/IISITv4p 381-393Burc 373.pdf

Burčik, V, DeLorenzo, G., Kohun, F., \& Skovira, R. (2008). Analysis of cultural effects on business curricular subject matter. Issues in Information Systems, IX(1), 207-216. 
Data Driven Conceptual Analysis of Globalization

Connor, P. E., \& Worley, C. H. (1991, Summer). Managing organizational stress. Business Quarterly, 56(1), 61-67.

Cyert, R. M. \& March, J. G. (1962, 1992). A behavioral theory of the firm, (2nd ed.). Cambridge, MA: Blackwell.

DeLorenzo, G., Kohun, F., \& Skovira, R. J. (2006). Analyzing the affect of g lobalizing business education on managerial and organizational theories: A frame work for research. Proceedings of the $7^{\text {th }}$ International Conference of the Faculty of Management Koper, University of Primorska, Slovenia, 7, 18331840.

Dooley, R. (2003). Four cultures, one company: Achieving corporate excellence through working cultural comple xity. Organization Development Journal, 21(2), 52-66.

Fried man, T. L. (2000). The Lexus and the olive tree. New York, NY: Farrar, Straus and Girou x.

Gannon, M. J. (2001). Understanding global cultures: Metaphorical journeys through 23 nations. Thousand Oaks, CA: Sage.

Geertz, C. (1973). The interpretation of cultures. New York: Basic Books.

Hofstede, G. (1983). National cultures in four dimensions: A research-based theory of cultural differences among nations. International Studies of Management and Organizations, 13(1-2), 46-74.

Hofstede, G. (1994). Uncommon sense about organizations: Cases, studies, and field observations. Thousand Oaks, CA: Sage.

Hofstede, G. (1994). Value Survey Module 1994. Retrieved February 23, 2009, from Value Survey Module: http://stuwww.uvt.nl/ csmeets/english.html

Hofstede, G. (2001). Culture's consequences: Comparing values, behaviors, institutions, and organizations across nations (2nd ed.). Thousand Oaks, CA: Sage.

Hofstede, G. \& Hofstede, G. J. (2005). Cultures and organizations: Software of the mind. New York: McGraw-Hill.

Hooker, J. (2003). Working across cultures. Stanford, CA: Stanford University Press.

Huang, L., Lu, M., \& Wong, B. K. (2003). The impact of power distance on email acceptance. Journal of Computer Information Systems, 44(1), 93-101.

March, J. G. (with Heath, C). (1994). A primer on decision making. New York, NY: The Free Press.

Mead, R. (1994). International management: Cross-cultural dimensions. Cambridge, MA: Blackwell.

Rowe, A. J., \& Mason, R. O. (1989). Managing with style: A guide to understanding, assessing, and improving decision making. San Francisco and London: Jossey-Bass.

Steming, B. W., \& Hammer, M. R. (1992). Cultural baggage and the adapt ion of expatriate A merican and Japanese managers. Management International Review 72(1), 77-89.

Tro mpenaars, F. (1994). Riding the waves of culture: Understanding diversity in global business. London: The Econo mist Books.

Tro mpenaars, F., \& Woolliams, P. (2003). Business across cultures. Chichester, England: Capstone.

Umanath, N. S., \& Campbell, T. L. (1997). Differential diffusion of information systems technology in mu ltinational enterprises: A research model. Information Resources Management Joumal, 7(1), 6-18. 


\section{Biographies}

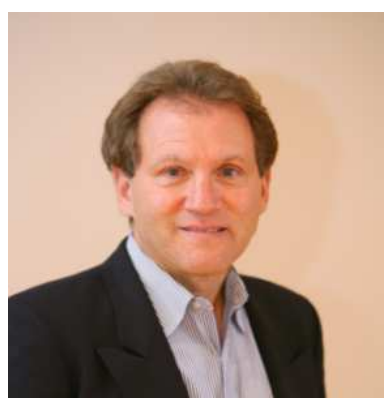

Gary J. DeLore nzo, D.Sc., Ass istant Professor of Mathematics and Computer Science at California University of Pennsylvania in California, Pennsylvania has spent more than 30 years in industry as programmer, analyst, consultant and manager before entering academia. In his academic career, he has gained a reputation as someone who brings people together, shares his industrial experience with students, and brings his energy and knowledge for collaborative efforts. He has led initiatives at the university in areas such as marketing and recruitment to increase student enrollment, service learning projects for information system majors, and startup business incubation projects. He and his students provide ongoing data base consulting and application support services for the John Heinz History Museum, Pitts burgh, PA, the largest history museum in Pennsylvania. He was a visiting professor at Robert Morris University in 2004 and 2008, and has presented and published his research both nationally and internationally.

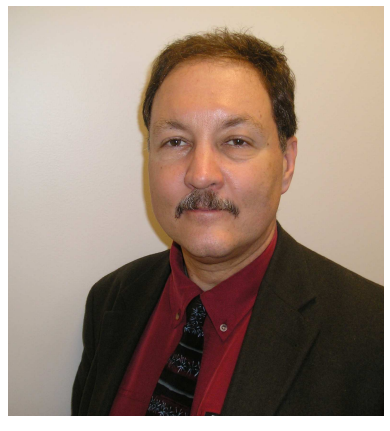

Frederick G. Kohun, Ph.D., Associate Provost and Unive rsity Professor at Robert Morris University in Pittsburgh, Pennsylvania has more than 33 years experience as a professor, department head, and academic administrator in the information systems field. He holds a bachelor degree in economics from Georgetown University, graduate degrees in economics and information science, from the University of Pittsburgh, and a Ph.D. in applied history in technology from Carnegie Mellon University. At Robert Morris University he led the design and implementation of eight technology based academic programs at the undergraduate and graduate level (including a doctoral program) as well as the attainment of ABET-CAC accreditation. He is known both nationally and internationally from his numerous publications and presentations in health informatics, decision support, technological impact, and culture as well as his active involvement as an accreditation evaluator and team leader.

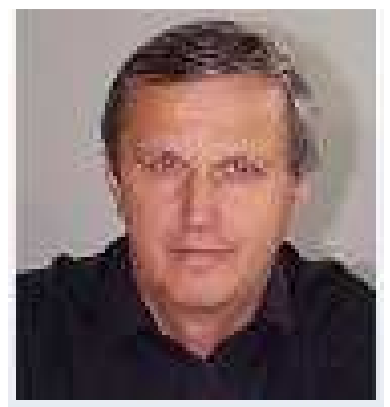

Dr. Vladimír Burčík PhD., Director of Academy of Communication, multimedia projects consultant at graphic studio Mr. Design. He gives lectures at the Department of Psychology at the Faculty of Arts, Comenius University and at the Department of Design at the Faculty of Fine Arts; specialises in CI, corporate communication, human computer interaction and www design; co-author of a monograph (Internet $\mathrm{v}$ riadení a obchode firmy) and of a textbook (Psychodiagnostika dospelých), author of many studies and programmes on CI, published in Slovakia as well as abroad. He worked on creating a corporate identity for the companies Slovakofarma, Milex Schärdinger, Slovenské design centrum, Palma, Rajo, Volkswagen, Všeobecná úverová banka, Ludová banka, Západoslovenská energetika, Telenor Slovakia, Eunet, EuroTel a S\&T Slovakia. He was the member of the jury of EUROPRIX in 1999. He is a member of the Board of directors of the World Summit Award (World Summit on Information Society). 
Alžbeta Belanová, Come nius Unive rsity, Bratislava, Slovakia is a doctoral student of Vladimir Burčík and fellow researcher on corporate identity.

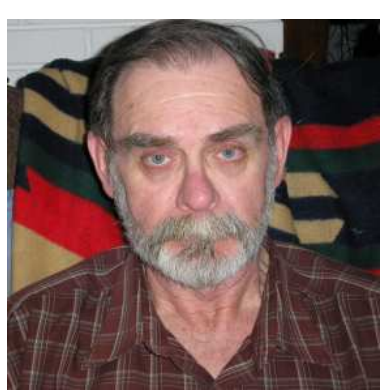

Robert Jose ph Skovira is Unive rsity Professor of Computer and Information Systems in the Department of Computer and Information Systems at Robert Morris University, Moon Twp (Pittsburgh) PA USA. He has taught undergraduate and graduate (MS) courses including Java Programming, Secure Programming, Global, Economic, Social, and Ethical Issues of Computing, Decision Support Systems, Information Design, and Ethical and Legal Issues of Technology. In the Doctor of Science program, he has taught Ethnography of Information Systems, Readings in Information Systems and Communications Research, and Writing the Proposal for Research courses. He has been a visiting professor at Comenius University, Bratis lava, Slovakia, in 1997 and 2006. Research interests include the anthropology of information, information and information system use within organizations (the infoscape, politics of information, information system bias), cultural and moral frameworks of information and information use, decision making and know ledge management, informing objects, information design and thinking visually. 